磁場内陽光柱の異常拡散之振動

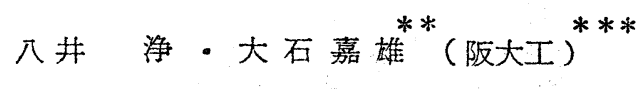

( 19965 年 4 月 6 日受玨)

Abstract

Relation between anomalous diffusion and oscillations of the positive column located in the longitudinal magnetic field in the range $0 \sim 2,200$ gauss was studied to examine the theory of Kadomtsev and Nedospasov.

By investigation of intensity and spectrum of the oscillations in the region of anomalous diffusion, higher harmonics of high frequency oscillation of the order $1 \mathrm{Mc} / \mathrm{s}$ were detected.

It is concluded that the excitation of high frequency oscillation is the essential cause of anomalous diffusion phenomenon in opposition to the theory of Kadomtsev and Nedospasov.

In addition, we investigated the set-in-magnetic-field of helical instability by changing the intensity of low frequency oscillation and found that the set-in-magnetic-field decreases with increasing intensity of pre-helical oscillations.

It may relate to the hysteresis characteristics of $E_{z}-B$ first proposed by Nakano et al.

* Anomalous Diffusion and Oscillations of the Positive Column in a Magnetic Field

* Kiyoshi Yatsui, Yoshio Inuishi

*** Department of Electrical Engineering, Faculty of Engineering, Osaka University. 
$\S 1$ は し がき

$$
\text { 八井・犬石 }
$$

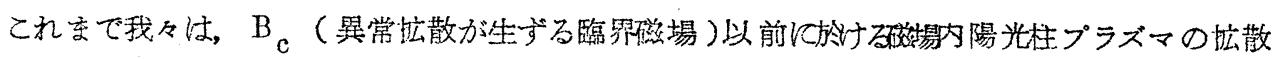
と低周波振動について調へ、低周波振動が著しい時には, $\mathrm{B}_{\mathrm{C}}$ 以前に於て子両極性拡散理論から 外れて，磁力線を横切る拡散が壇大する現鱼を兒出したが (1)，(2)，(3)，今回，更に強磁場に至 る迄の拉散と振動の関係について, 一連の定量的な実験を行ん, 與味ある結果を得たので報告す る。

今回の実験の主要点悢次の通りである。

(i) $\mathrm{B}_{\mathrm{c}}$ 以前の振動の性質在知西囊

(ii) $\mathrm{B}_{\mathrm{c}}$ 以前の振勳が $\mathrm{B}$ 亿及优吉影製と $\mathrm{B}_{\mathrm{c}}$ への移行状態

(iii) 露子温度の $\mathrm{B}_{\mathrm{c}}$ 前後の詳細な变化

(iv) 半径方向電位差の異常恼散領域での詳細な变化

(V) 異常脏散領域での noise spectrum

\section{§2 溉定原理・方法及び装置}

\section{2-1 䭰定原理及び方法}

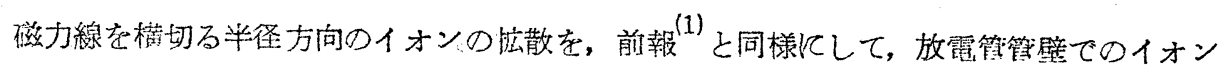
電流 $\mathrm{j}_{\mathrm{i} \text { w }}$ と半径力向のイオン密度分布 $\mathrm{n}_{\mathrm{i}}(\mathrm{r})$ の瀴定から調べた。

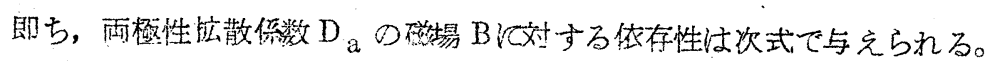

$$
\frac{D_{a}^{*}(B)}{D_{a}(0)}=\frac{j_{i w}(B)}{j_{i w}(0)} \cdot \frac{\left.\Delta n_{i}(0)\right|_{r=w a l l}}{\Delta n_{i} \text { (B) }\left.\right|_{r=w a l l}} .
$$

但し,

$\mathrm{D}_{\mathrm{a}}(\mathrm{O})$; 両極性摭散保数 $(\mathrm{B}=0)$

$\mathrm{D}_{\mathrm{a}}^{*}(\mathrm{~B}) ; \quad " \quad$ " $\left.\mathrm{B} \neq 0\right)$

$\mathrm{j}_{\mathrm{i} \mathrm{w}}(0)$; 放電管管壁でのイオン電流密度 $(\mathrm{B}=0)$

$\mathrm{j}_{\mathrm{iw}}(\mathrm{B}) ; \quad$ " $(\mathrm{B} \neq 0)$

$\left.\frac{\Delta \mathrm{n}_{\mathrm{i}}}{\Delta \mathrm{r}}(0)\right|_{\mathrm{r}=\text { wal l }}$; 放電算管壁でのイオン密度勾配 $(\mathrm{B}=0)$ 


\section{磁場内陽光柱の暴常拡散々振動}

$\frac{\Delta \mathrm{n}_{\mathrm{i}}}{\Delta \mathrm{r}}$ (B) $\left.\right|_{\mathrm{r}=\mathrm{wa} 11}$; 放電管管壁でのイオン密度勾配 ( $\mathrm{B} \neq 0$ )

台, こてで (a) 放電管筐壁でのイオン電流； $\mathrm{j}_{\mathrm{i} w} \quad$ (b) イオン密度； $\mathrm{n}_{\mathrm{i}}$ (c) 放電

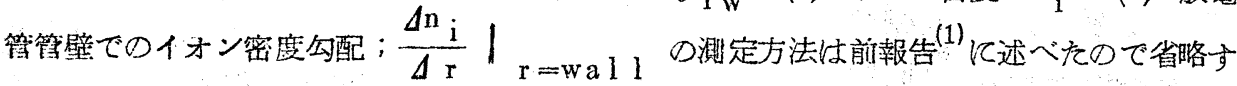
万。

\section{$2-2$ 実 験 装}

（第1図）に実験装置の概要を示す。

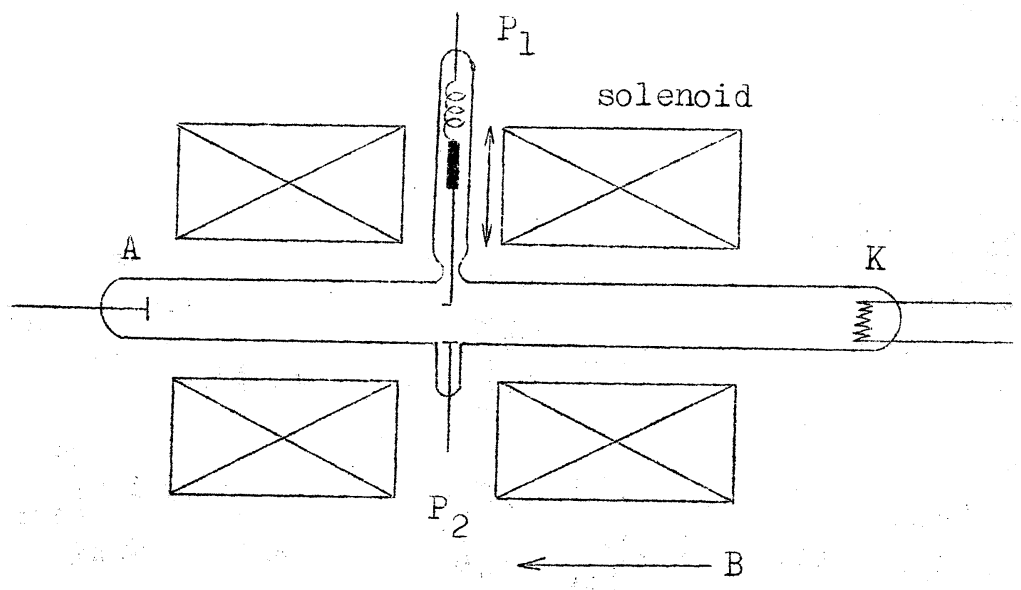

A; anode $\mathrm{K}$; hot cathode

$\mathrm{P}_{1}$; movable probe ( cylindrical)

$\mathrm{P}_{2}$; wall probe (disk)

第 1 図実験装置 


$$
\text { 八井。犬 石 }
$$

(a) 放 電 管

気体； $\mathrm{A}_{\mathrm{r}}$. 気压； $0.1 \mathrm{~mm} \mathrm{Hg}$

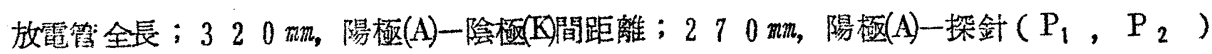

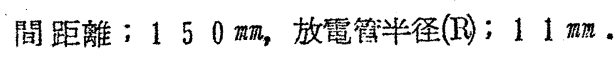

$\mathrm{P}_{1}$; 半径方向可動探針, $0.1 m \boldsymbol{m} \phi 2 \mathrm{~m}$ ：モリブデン製. (半径方向のイオン密度分布 及び Potential 分布測定, 並びに振動測定用)

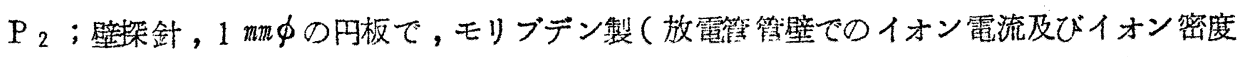
测定，立び振動测定用）

䏌，振動测定は(1) $\mathrm{P}_{1}$ ，(2) $\mathrm{P}_{2}$ ，(3) Aよbpick up して $0.5 \mu \mathrm{F}$ よンデンサを直 列に插入した後, シンクロスコープで籏測した。

(b) 磁場用コイル

磁場強度 B；0２,200 gauss. 連続可变

$\S 3$ 実 験 結 果

3 - 1 放電筹管壁への拡散流（イオン電流）の磁埸依存性

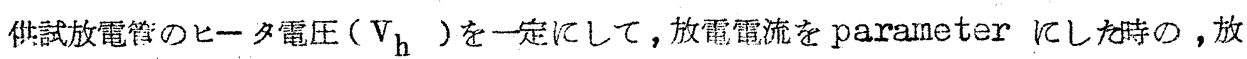

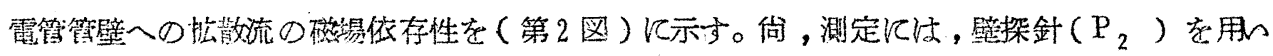
底。

図上り,放電電流 $\mathrm{I}_{\mathrm{d}}=5 \mathrm{~mA}$ では $\mathrm{B}_{\mathrm{c}}=1,360$ gauss で, 又 $\mathrm{I}_{\mathrm{d}}=10 \mathrm{~mA} ゙$, $B_{c}=1$ A 80 gauss $て ゙$, Helical Instability 依る異常拡散領域飞入る事が分か る。

$3-2$ 臨界磁場 $\left(\mathrm{B}_{\mathrm{c}}\right)$ ) 放電電流依存性

ヒ一タ電卧 $\left(\nabla_{\mathrm{h}}\right)$ を一定にして, parameter である放電電流 ( $\left.\mathrm{I}_{\mathrm{d}}\right)$ を $5 \sim 20 \mathrm{~mA}$

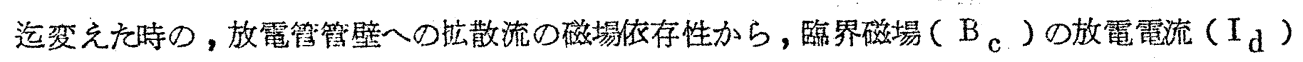
に依る変化を示したのが，(第了図)である。

(第 3 図)の傾向は, Hoh-Lehnert の実験 ${ }^{(4)}$ と良く一致し，乙れは及,放電電流 ( $\left.I_{d}\right)$ が増加すると，綎電場 $\left(\mathrm{E}_{\mathrm{z}}\right)$ が減少する陽光柱ブラズマの特性及び Helical Instability の理論からも，reasonableな結果と思われる。 
磁・場内陽光柱の異常搪散と振動

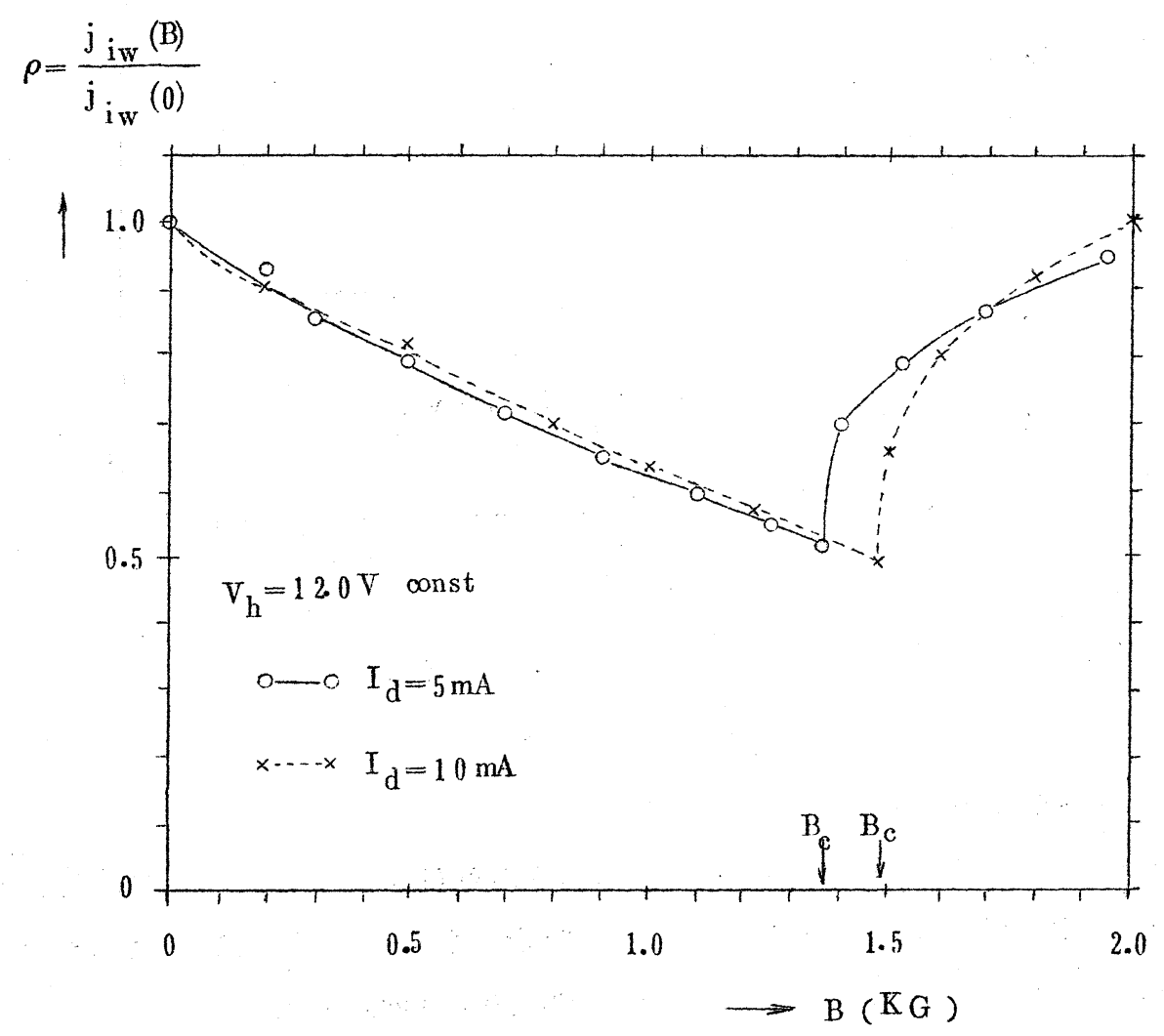

第 2 図

放電管管壁への拡散流の磁場依存性 


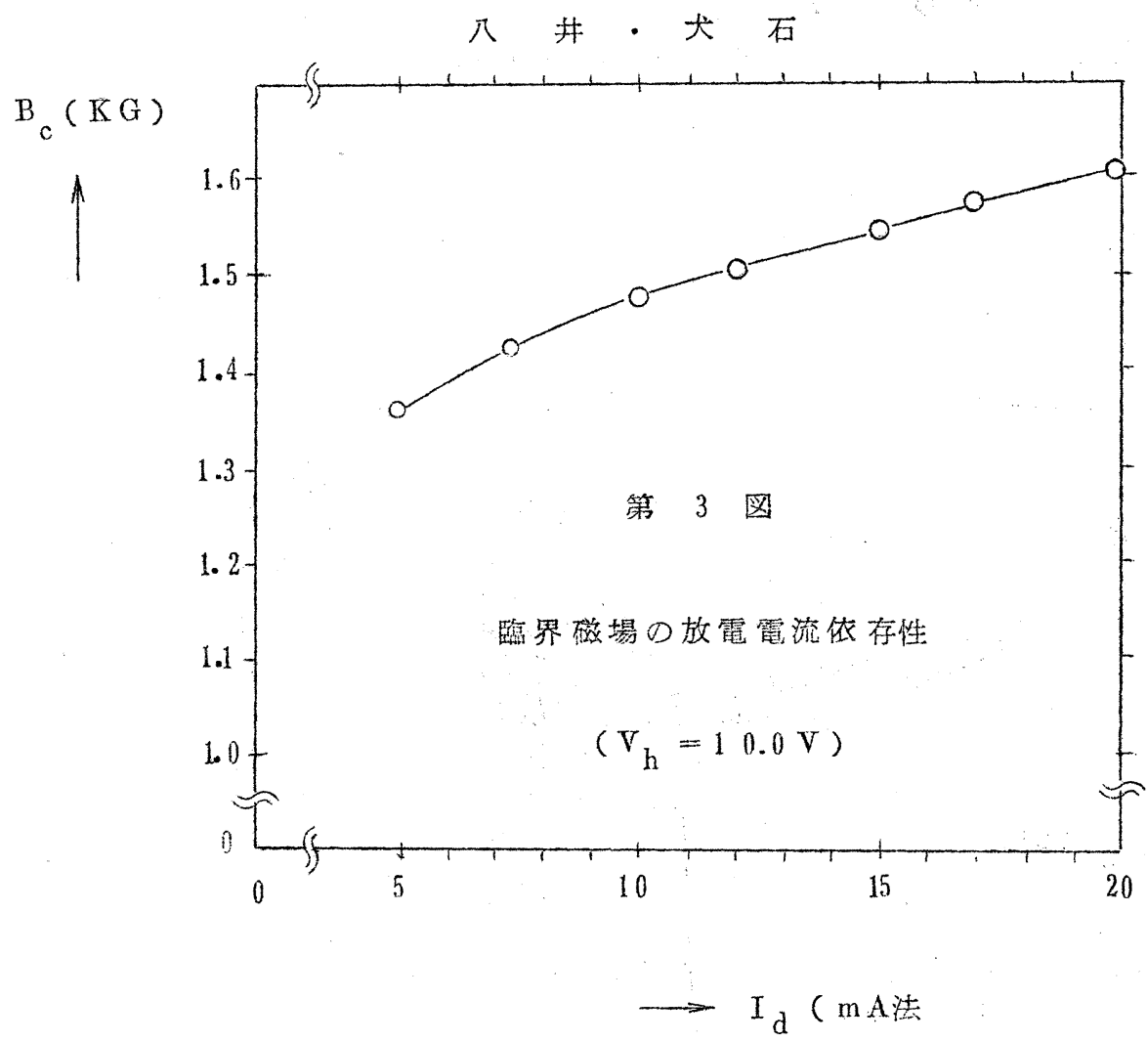

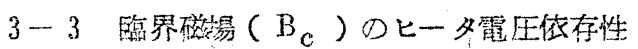

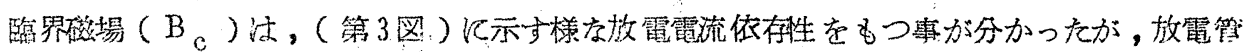

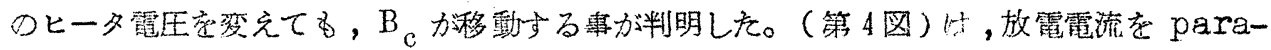

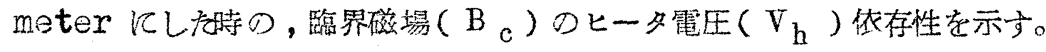

図より，ヒ一夕電压 $\left(\mathrm{V}_{\mathrm{h}}\right)$ 在大くすると，臨界磁場 $\left(\mathrm{B}_{\mathrm{c}}\right)$ が高くなるのが注目される。

$3-4$ 電子温度 $\left(\mathrm{T}_{\mathrm{e}}\right)$ ) 磁埸依存性

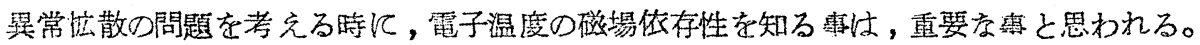

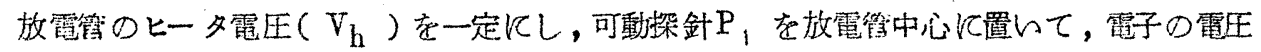

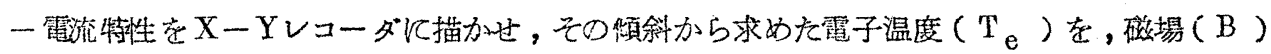
の関数として示したのが(第 5 図)である。 
磁場内陽光柱の異常拡散と振動

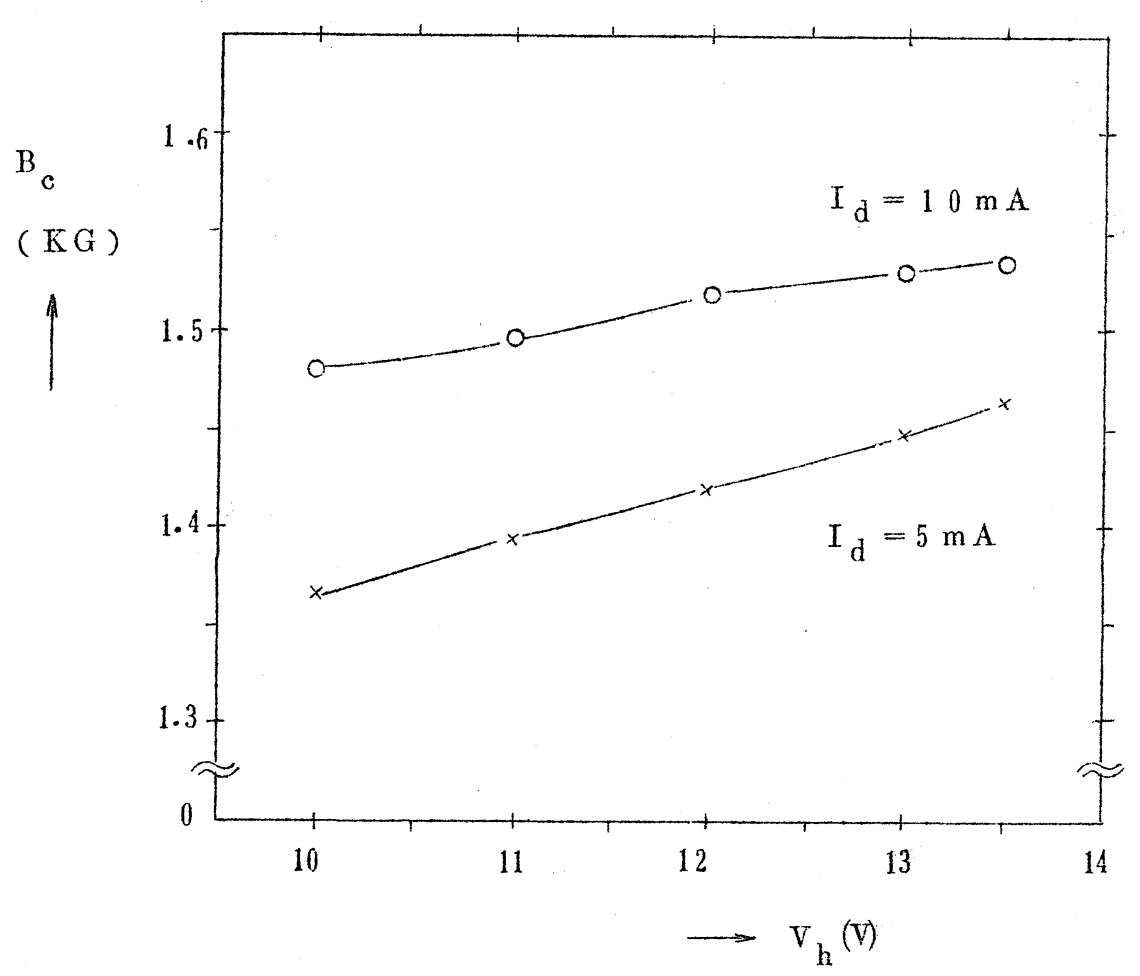

第 4 図

臨界磁場のヒータ一電王依存性 


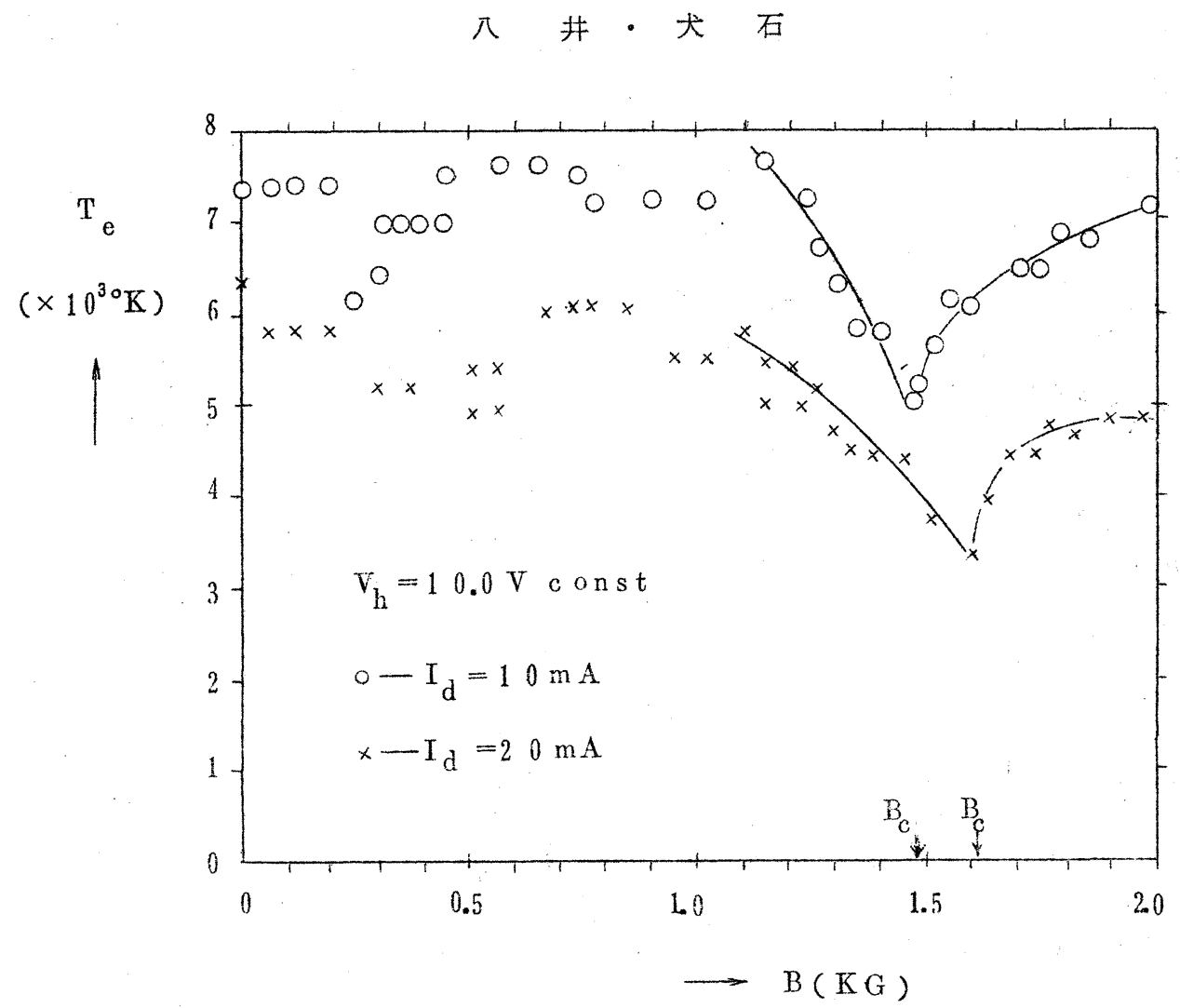

第 5 図

電子温度の磁場依存性

図上り，臨界磁場 $\left(\mathrm{B}_{\mathrm{c}}\right)$ 飞於て, 電子温度 $\left(\mathrm{T}_{\mathrm{e}}\right)$ の急激な增加か認められ，又，後に述 べる低周波振動の磁場依存性に於ても，振動電王の急激な增大が愉知された。

\section{3-5 半径方向電位差の磁場依存性}

磁力線を横切るイオンの搪散を考える時, 半径方向電位差 $(\mathrm{V}(\mathrm{r}))$ の磁場位存性を知る事に は、重要な意味がある。

可動探針 $\left(P_{1}\right)$ を放電管中心纪置々て， $P_{1}$ と壁探針 $\left(P_{2}\right)$ の各々の floating potential の差から求めた半径方向電位差 $(V(r))$ の磁場依存性を示したものが(第6図) である。 
磁場内陽光柱の異常拡散と振動

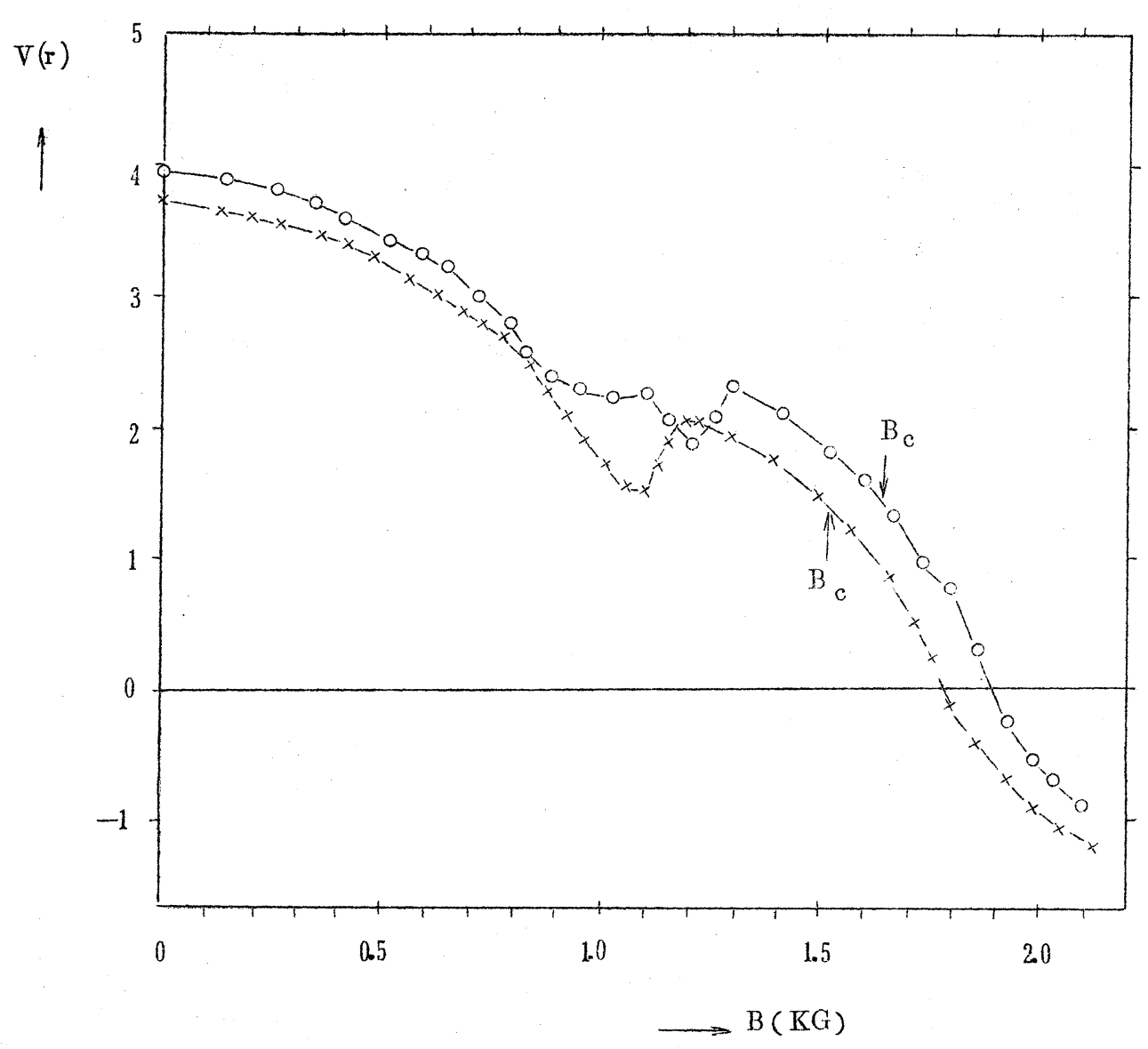

第 6 図

半径方向電位差の磁場依存性

$$
\begin{array}{ll}
\times-\mathrm{I}_{\mathrm{d}}=7.5 \mathrm{~mA} . & \mathrm{V}_{\mathrm{h}}=10.8 \mathrm{~V} . \\
0-\mathrm{I}_{\mathrm{d}}=20 \mathrm{~mA} . & \mathrm{V}_{\mathrm{h}}=14.0 \mathrm{~V} .
\end{array}
$$




\section{八井 - 犬 石}

図より明らかな椂に，臨界磁場（B $\left.B_{c}\right)$ をんくらか越えた磁場で，半径 方向電位羙の逆転が 認为られる。

\section{$3-6$ 磁場内陽光杜プラズマの振動}

（a）低周波振動の磁場依存性

（第 7 図）は，放電電流 $\mathrm{I}_{\mathrm{d}}=5 \mathrm{~mA} ，$ ヒ一名電压 $\mathrm{V}_{\mathrm{h}}=12.5 \mathrm{~V}$ 埸合の，探針 $\mathrm{P} ，$ 上

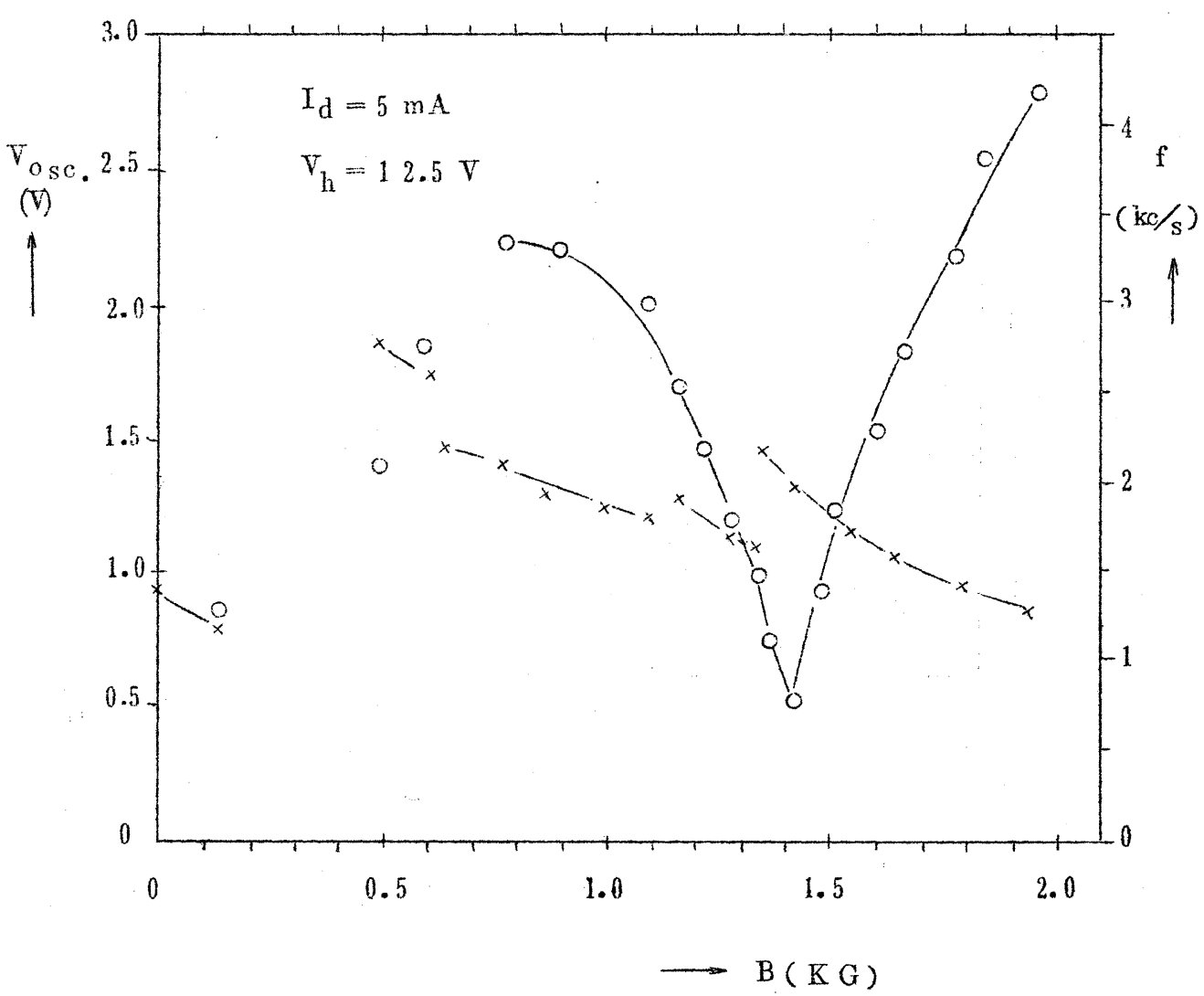

第 7 図

低周波振動の磁場依存性

$$
\begin{aligned}
& \text { - Vosc. (peak to peak) (V) } \\
& \times-f(k c / s) .
\end{aligned}
$$




\section{磁齐内陽光柱の異常拡散と振動}

b pick up しを低周波振動電圧 ( peak to peak) 及び周波数の磁場依存性を示す。

少，振動周波数忙，探針 $\mathrm{P}_{1}, \mathrm{P}_{2}$ 及ひ陽極 $\mathrm{A}$ 上pick up しても，殆んど变化は認 められなかった。

又, 放溉雷流をparaneter KLて求的论低周波振動の磁場依存性に於て，振動電压の jump 加求めた $\mathrm{B}_{\mathrm{c}}$ の放電電流依存性怯, 放電管管壁への jump から求めた $\mathrm{B}_{\mathrm{c}}$ の放電 電流依存性（第 3 図）に良く一致し，更に，電子温度の jump加求为た $\mathrm{B}_{\mathrm{c}}$ の放電電流依 存性（第 5 図）とも非常记息く一致する。

（b）低周波振锄電圧のヒ一夕電压依存性

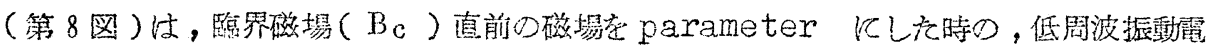

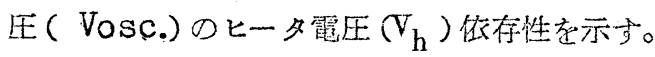

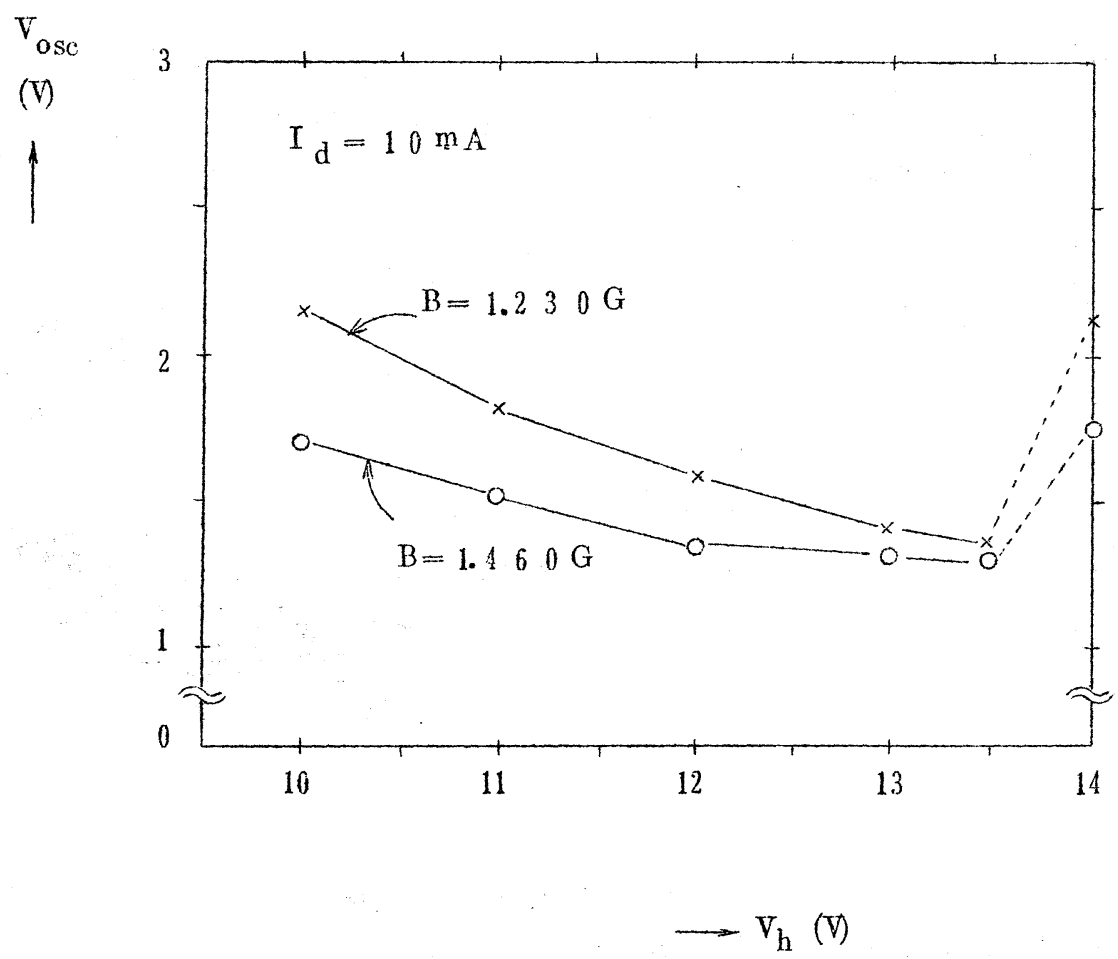

第 8 図

低周波振锄電王のヒータ電仕依有牲 


$$
\text { 八井・ }
$$

図より, ヒータ電圧 $\mathrm{V}_{\mathrm{h}}=10 \sim 13.5 \mathrm{~V}$ の範囲内では, $\mathrm{V}_{\mathrm{h}}$ の增大と共に磁場内陽光柱 に発生する低周波振動の振動電压（peak to peak）仕減少し, 乙れは臨界磁場のヒ一タ 電王依存性（第 4 図）とる関連があると思われる。

(c) 磁場内陽光柱の noise spectrum

磁場中プラズマの異常搪散と，それに伴って急速に増大する低周波振蚝については， Kadomtsev-Nedospasovの理論(5)が一㙺した説明を与えているが，彼等の理論にも種々 の開題点があり，その検討に壮，異常抎散領域での振動のintensity及び spectrum ○正確㾌知識が必要となるであるう。

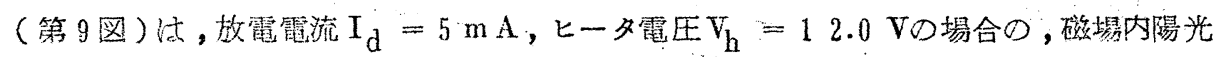
杜プラズマの noise spectrum である。

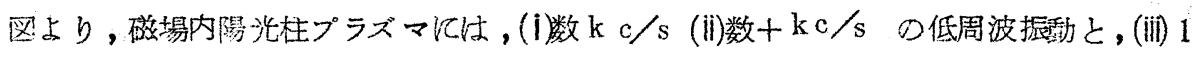

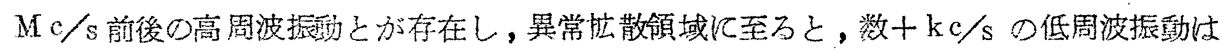

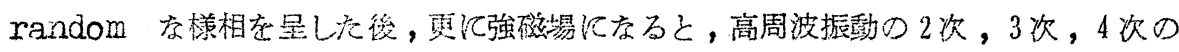
higher harmonics が䶍われる事が分かる。

（d）高周波振動電圧の磁場依存性

（第 10 図）は，放電電流 $\mathrm{I}_{\mathrm{d}}=5 \mathrm{~m} \mathrm{~A}$, ヒ一タ電圧 $\mathrm{V}_{\mathrm{h}}=12.0 \mathrm{~V}$ の場合，高周波振動 のfundamental modeである $\mathrm{f} \sim 0.6 \mathrm{Mc} / \mathrm{s}$ の振動電化の磁場依存性 (実線) 宗す。 份，比較のをめに，(第 9 図)にみられる数 $+\mathrm{kc} / \mathrm{s}$ の低周波振動電圧の磁場低存性を， 点綄で示した。

図より：30〜70 k c/s の低周波振動電圧は, 磁場の增大と共に減少し, $\mathrm{B}_{\mathrm{c}}$ で急激 去增大を示すが, $\mathrm{f} \sim 0.6 \mathrm{Mc} / \mathrm{s} \oplus$ 高周波振動電圧は, 磁場の增大と共㵊初少し增大し

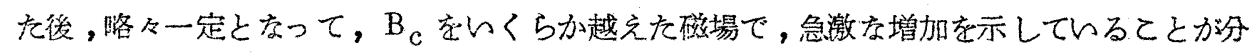
かる。

\section{$\S 4$ 検討}

4-1 臨界磁場 ( $\left.\mathrm{B}_{\mathrm{c}}\right)$ ) 低周波振動電压依る变化

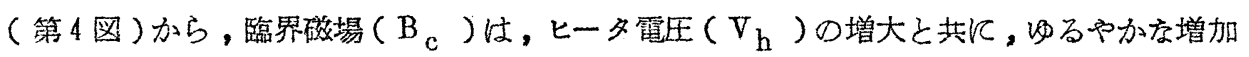
を示寸事が明らが次った。

てれは, $\mathrm{V}_{\mathrm{h}}$ の増大に伴って, 磁場内陽光柱で, Helical Instabilityへの突入がし 
磁場内陽光柱の晎常拉散と振動

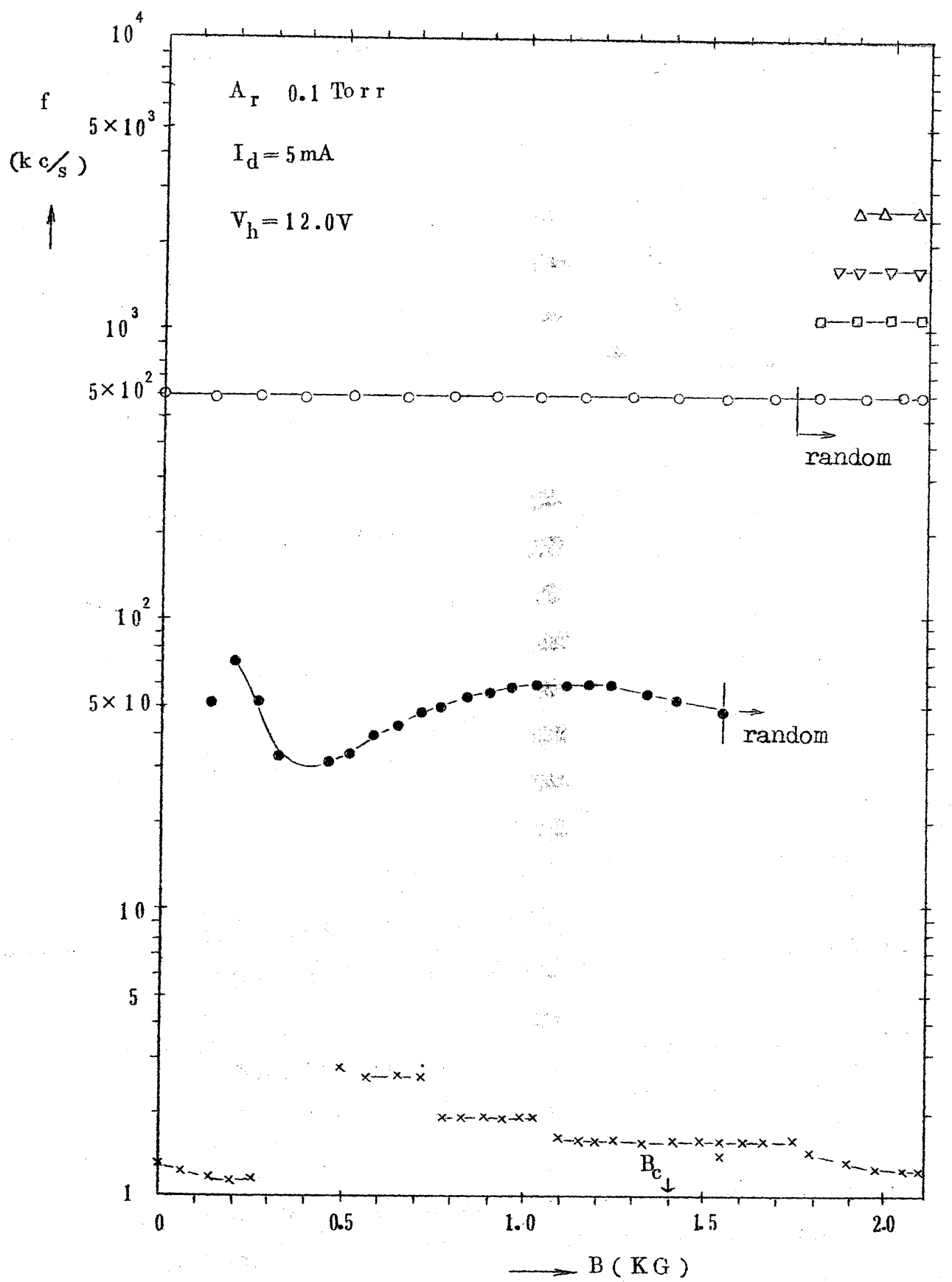

第 9 図

磁場内陽光柱の noise spectrum 


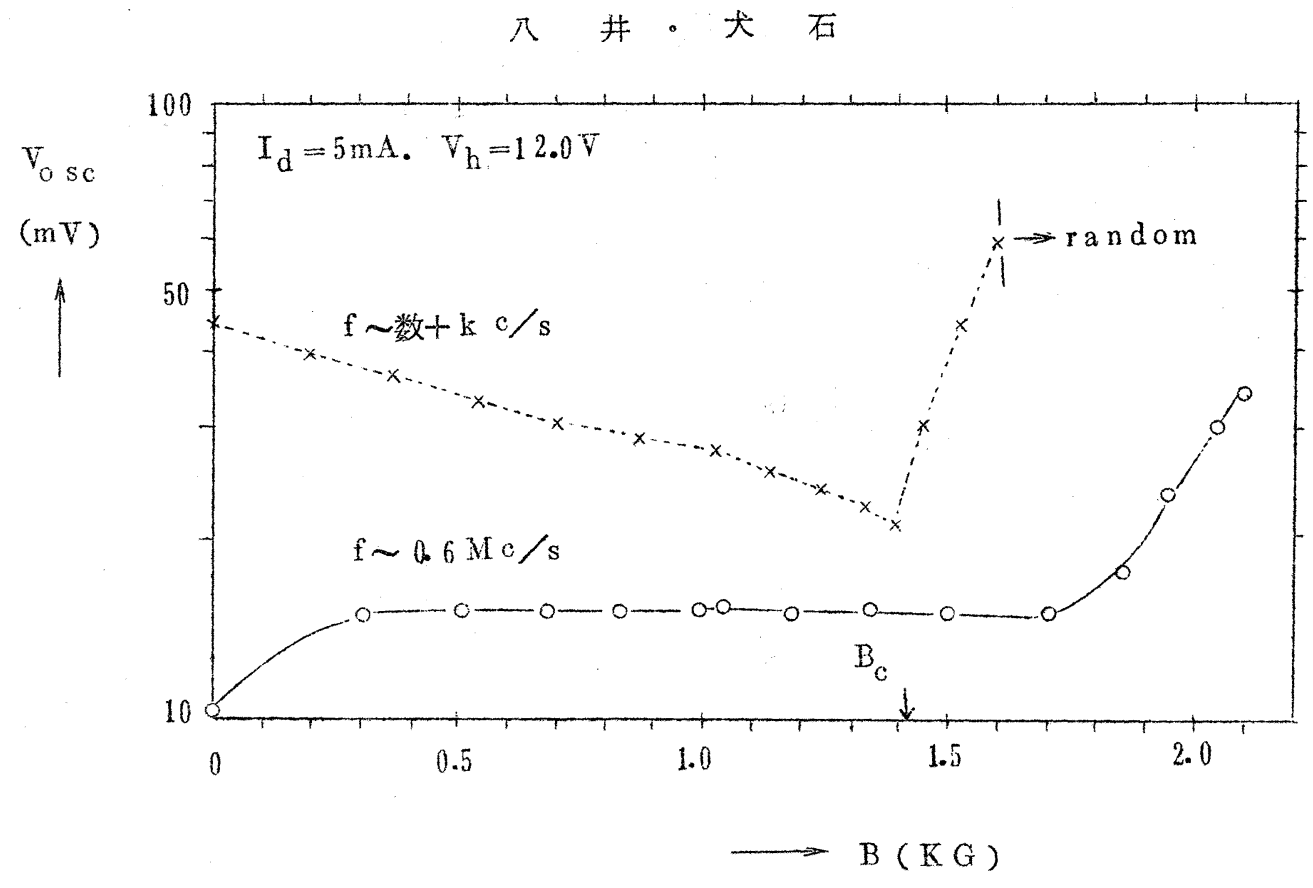

第 10 図

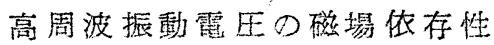

にくく尝吕何らかの機構が存在する事走暗示するすのと言えよう。

その一例として，磁場内陽光柱飞発生する低周波振動が考えられる。

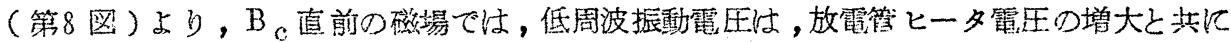
減少する事から，低周波振動が Helical Instabilityの発生に，何らかの影響を及棌し ている，と考える事が出来る。

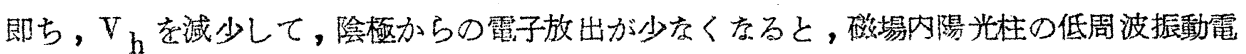
王が堌大し，それがタネ”となって, Helical Instabilityへの突入が早く生ずる事 得当。

磁埸内陽光柱が，一度異常拉散領域に入れば，プラズマは乱流的索様相を呈すであるらから，

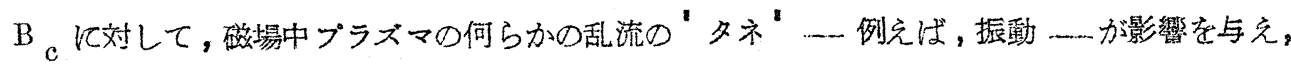

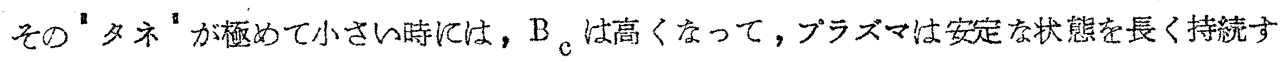
るものと思われる。

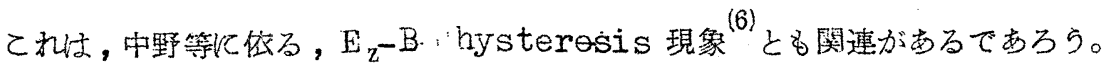


磁場内陽 光杜の異常应散と振動

$4-2$ 低周波振陲（数 $\mathrm{k} \mathrm{c} / \mathrm{s}$ ) の性質

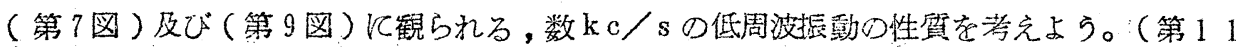

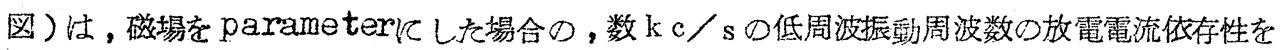
示す。

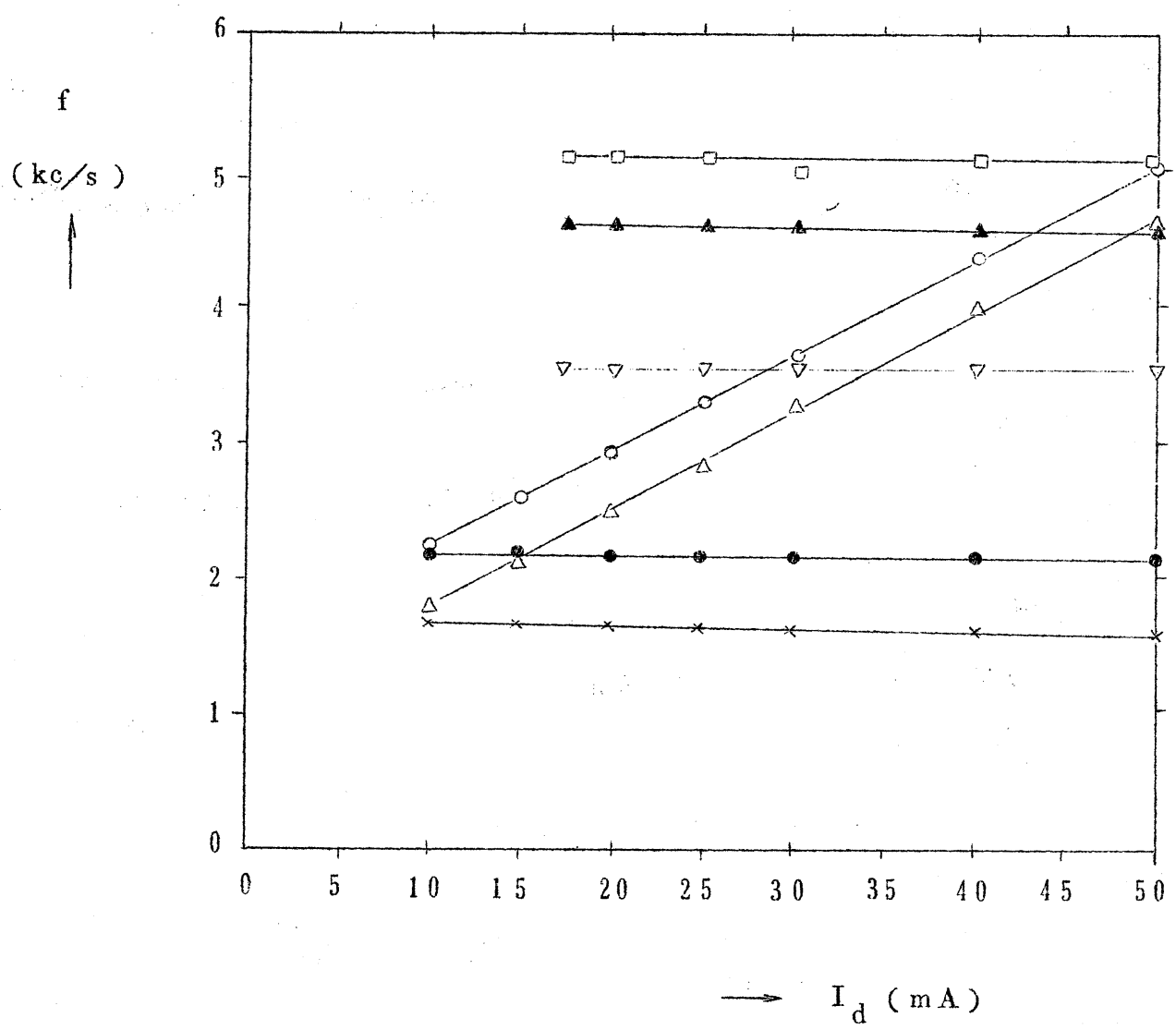

第 111 図

低周波振動周波数の放電電流依存性 $\left(\mathrm{V}_{\mathrm{h}}=10.0 \mathrm{~V}\right.$ cons $\left.\mathrm{t}\right)$

但L, $O-B=0, \triangle-B=130 G, \quad \square-B=260 G$,

$\triangle-B=380 \mathrm{G}, \quad \nabla-\mathrm{B}=650 \mathrm{G}$,

$-\mathrm{B}=1,160 \mathrm{G}, \quad \times-\mathrm{B}=1,930 \mathrm{G}$ 


$$
\text { 八井・犬石 }
$$

因より現象論的にみて, $\mathrm{B}=0 \sim 200$ gauss の低周波振動と， $\mathrm{B}>200$ gauss の低 周波振動とは，別の性質のるのである車が予想される。

B>2 00 gauss の低周波提動壮,後の 2 ケのフォトトランジスタに依る管軸に沿ら場所 的分布，及び波長の測定から，波長が数cmの移動縞に位る振動が主で，強磁場で恃，探針部近 傍一险極間で殆んど pick up されず，陽極一探針部近傍にのみ存在する乘が判明した。

合，低周波振動の磁場依存性（第７図）で，B２０〔 gauss 前後にみられる不連続性注， 放電等管壁への脏散流の磁場依存性（第 2 図），電子温度の磁場依存性（第 5 図），及び半径

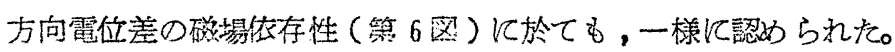

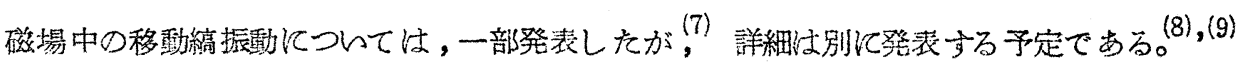

\section{4-3 半径方向霡位差逆鞋}

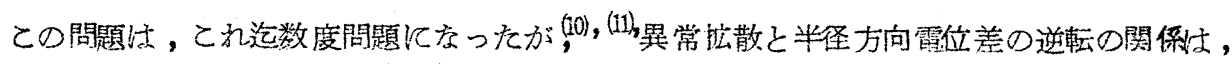
未に゙正整に把握されて㤝いない。

(第 6 図) から言元万事忙,電位の逆転が生ずる磁場に, 当然の專ながら, 放電電流依存性

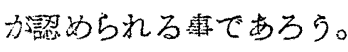

隄光柱理論から，雪位差Vの半径方向成分法，

$$
\frac{\partial \mathrm{V}}{\partial \mathrm{r}}=\frac{\mathrm{D}_{\mathrm{er}}^{*}-\mathrm{D}_{\mathrm{i}}^{*}}{\mu_{\mathrm{e}}^{*}+\mu_{\mathrm{i}}^{*}} \frac{1}{\mathrm{n}} \frac{\partial \mathrm{n}}{\partial \mathrm{r}}
$$

但し, $\mu_{\mathrm{e}}^{*}, \mu_{\mathrm{i}}{ }^{*}$; 磁場中の, 電子及びイオンの移動度

$\mathrm{D}_{\mathrm{er}}{ }^{*}, \mathrm{D}_{\mathrm{ir}}{ }^{*}$; 磁場中の，電子及びイオンの半径方向拡散係数

$\mathrm{n}$; 荷電粒子密度

で表わされるから，異常㹡散領域での半径方向電位差の逆転は，強磁場での電子及びイオンの サイクロトロン周波数の相異のために, $\mathrm{D}_{\mathrm{i}}{ }^{*}>\mathrm{D}$ er ${ }^{*}$ となって, イオンの半径方向の搪散が 電子のそれを上回る專を意味し，磁力線を横切るイノン略散の重要性を示するのと言えよう。

今后, 異常搪散領域での, 半径方向電位差の整場依存性の更に多くのデータが待えれる。

4-4 Kadomtsev-Nedospasov 理論の検討

ここて簢単に; Kadomtsev-Nedospasov 理論吕振返ってみよう。 
磁場内陽光柱の異常搪散と振動

彼等は，Lehnert の仮定 ${ }^{(2)}$ から出発して，電子及びインンと対する（1）連続の方程式，

(2) 運租の方程式, (3) poisson の方程式, の方程式系に対して, (a) $\mathrm{n}_{\mathrm{e}}=\mathrm{n}_{\mathrm{i}}=\mathrm{n}$,

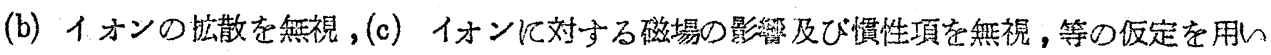

$\tau$,

$$
\begin{aligned}
& \frac{\partial \mathrm{n}}{\partial \mathrm{t}}+\operatorname{div} \mathrm{nv}_{\mathrm{i}}=\frac{\partial \mathrm{n}}{\partial \mathrm{t}}+\mathrm{div} \mathrm{n}_{\mathrm{e}}=\mathrm{Zn} \\
& \frac{\mathrm{kT} \mathrm{T}_{\mathrm{e}}}{\mathrm{mn}} \nabla \mathrm{n}=-\frac{\mathrm{e}}{\mathrm{mc}} \nabla_{\mathrm{e}} \times \mathrm{H}+\frac{\mathrm{e}}{\mathrm{m}} \nabla \nabla-\frac{v_{\mathrm{e}}}{\tau} \\
& \mathrm{v}_{\mathrm{i}}=-\mathrm{b}_{\mathrm{i}} \nabla \mathrm{V}
\end{aligned}
$$

の基䂠方程式を得た。

そして， small amplitude perturbation の取报い俵って得られた分散式から， 臨界磁場 $\left(\mathrm{B}_{\mathrm{c}}\right)$ より僅办に大を磁場で磁場内陽光柱江登生する正弦波の振動数 $\mathrm{f}$ は,

$$
f \sim 10 \cdot \frac{1}{\omega_{e} \tau_{e}} \cdot \frac{b_{i}}{b_{e}} \cdot \frac{D_{e}}{a^{2}}
$$

但し, $\omega_{\mathrm{e}}$; 電子のサイクロトロン䧓波数

$\tau_{\mathrm{e}}$ ：撆子と中性粒子との衝乫時間

$b_{e}, b_{i}$; 露子及びイオンの移颠度

a ; 放電籍半径

$\mathrm{D}_{\mathrm{e}}$; 雪子の搪散係数

で与えられ，Hoh-Lehnertの実験 条件下では，10 k c/s 程度の低周波振動核当する， と説明した。

然し，彼等の理論飞る，多くの問題点がある様に思われる。

例えば，(第6図）の半径方向電位差の磁場依存性から，検討 $(4-3)$ ) 述へた様に，

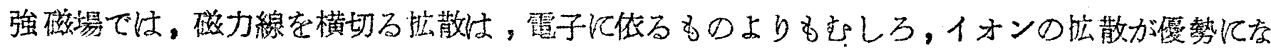
万 $\left(D_{\mathrm{i} r}^{*} \sim \frac{D_{i 0}}{\left(\omega_{i} \tau_{i}\right)^{2}}>D_{e r}^{*} \sim \frac{D_{e 0}}{\left(\omega_{e} \tau_{e}\right)^{2}}\right)$

であろうから，Kadomtsev-Nedospasovの理論で用いられた仮定(b)の粎に，イオンの拉散 を最初から無視するのは，正しくない手続と䨐えるであるう。 


$$
\text { 八井 ・ 犬 石 }
$$

次に，(第 9 図)及び(第 10 図)の実験結果を眺めてみよう。

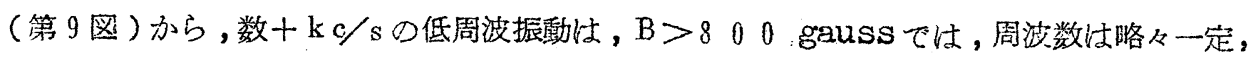
又，磁場の增大と共に減少特性を示した振動電圧沬， $\mathrm{B}_{\mathrm{c}} \sim 1,400$ gauss で急激な增大を

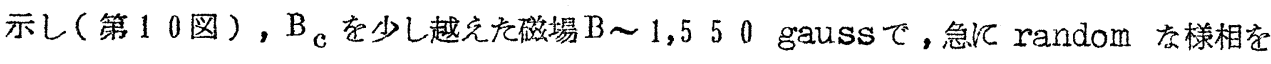
呈してし亡う。

これに対して, 高周波振動は, $\mathrm{f} \sim 0.6 \mathrm{Mc} / \mathrm{s}$ の基本波が常に存在し，数十 $\mathrm{kc} / \mathrm{s}$ の低周波 振動が random Kなる磁場を越えてから，B〜1,800 gaussで，約 $1.1 \mathrm{M} / \mathrm{s} の$ 第 2 次

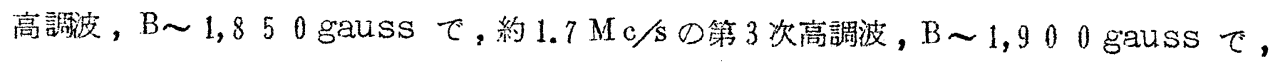
約 $2.5 \mathrm{Mc} / \mathrm{s}$ の第 4 次高裙资が現われ，各振動モードの set-in-magnetic-field 岋異なり, higher mode Kなる程, set-in-magnetic-field が高くなる萧が注 目される。

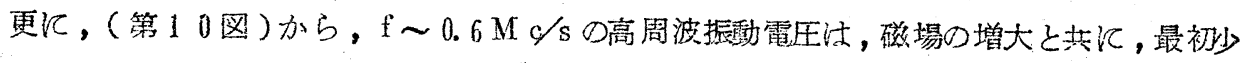

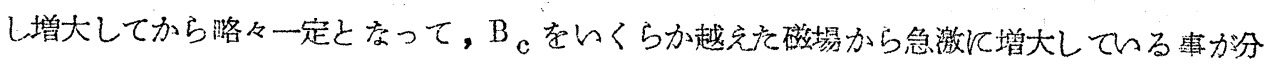
加る。

己れらの点から, 磁場内陽光柱の異常抎散の出現と, $1 \mathrm{Mc} / \mathrm{s}$ 前後の高周波振動の励起とは， 密接な関係があると言えるであるう。

てれは、Kadomtsev-Nedospasov つ理論で注考えられていないるての理由として, 彼等 の理論では，仮定(a)で， $\mathrm{n}_{\mathrm{e}}=\mathrm{n}_{\mathrm{i}}=\mathrm{n}$ と置いて，磁場内陽光柱プラズマを一流体モデルで扱 っ庆ために，雷子とイオンが同じ位相で運動する低周波振動分岐しか着目しなかった繁に依る と考えられる。

彼等の理論的欠宿を修正した磁場内陽光柱の振彭之不安定性については，市川一三沢 ${ }^{(13)}$ ，

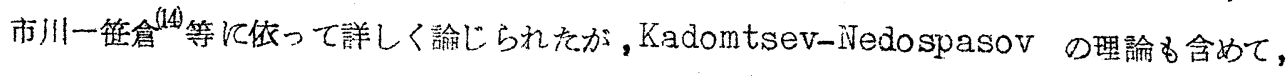

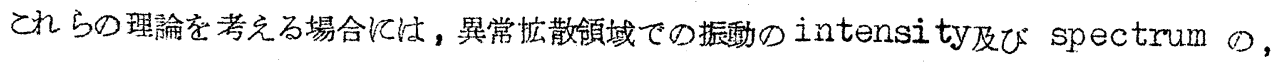
更に詳しい実験データが望交れるであるう。

\section{$\S 5$ 結 論}

磁場内陽光柱の異常拉散の現象を，振到との䦭連で実験的に研究した結果，次の諸点か明らか になった。

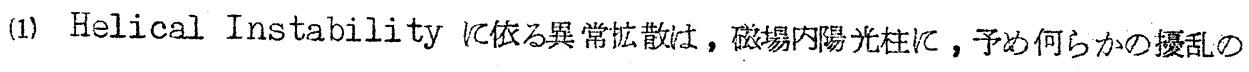


磁場内陽光柱の暴常抾能と振動

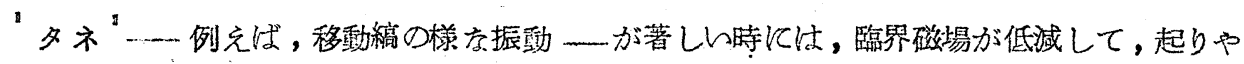
すく疗る。

（2）異常抬散領域では，半径方向電位差の逆転が生じ，磁力線を横切る胎散は，イオンに依る 搪散力泍質的になる。

(3) 異常搪散の出現と，1Mc/s 程度の高周波振動の厉起とは，密接交関係がある。

(4) 簧常拡散領域では, 高周波振勒の higher harmonicsが現われ, higher mode

になる程，set-in-magnetic-field 岋筒くなる

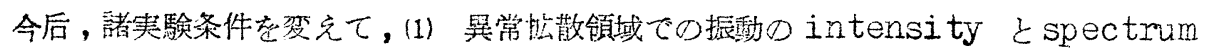

(2) 商周波振動の higher harmonics (3) 各振動比ドの growth rate, 波長及び

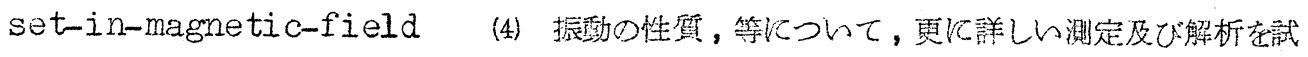
みる予定である。

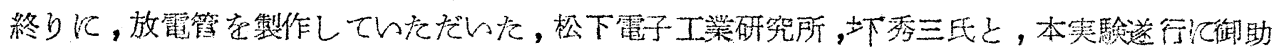

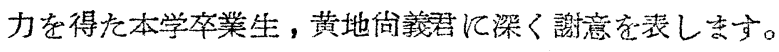

参老文献

（1）八井，久保，犬石；焚融合研究 $12(1965) 510$

(2) 八井, 久保, 犬石; 物理学会, 筙 19 回年会, 4, $6 \mathrm{a}-\mathrm{R}-2$

(3) K. Yatsui, U. Kubo and Y. Inuishi; J. Phys. Soc. Japan (投稿中)

(4) F. C. Hoh and B. Lehnert; Phys. of Fluids 3 (1960) 600

(5) B. B. Kadomtsev and A.V. Nedospasov; J. Nucl. Energy

Part C. I (1960) 230

(6) 中野, 今津他; 物理学会, 昭 39 , 春, $4,3 \mathrm{p}-\mathrm{P}-3$

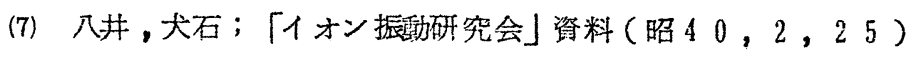

(8) K. Yatsui, T. Ohji and Y. Inuishi; Jap. J. Appl. Phys. (投稿予定 )

（9）八井，黄地，犬石; 核融合研究 (投稿予定)

(10) 中野, 今津他; 物理学会, 第 19 回年会, $4,6 a-R-4$ 


$$
\text { 八井 ・ 犬 石 }
$$

(11) G. V. Gierke and K. H. Wöhler; Nuclear Fusion, Suppl.

$$
\text { Part } 1 \text { (1962) } 47
$$

(12) B. Lehnert; Proceedings of the 2nd United Nations Conference on the Peaceful Uses of Atomic Energy, Geneva, 32 (1958) 349

(13) 市川, 三沢; 核融合研究 $7\left(\begin{array}{llll}1 & 9 & 6 & 1\end{array}\right) 445$

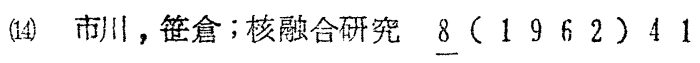

